\title{
The Proangiogenic Capacity of Polymorphonuclear Neutrophils Delineated by Microarray Technique and by Measurement of Neovascularization in Wounded Skin of CD18-Deficient Mice
}

\author{
Ruth Schruefer $^{\mathrm{a}}$ Silke Sulyok $^{\mathrm{b}}$ Jürgen Schymeinsky ${ }^{\mathrm{a}}$ Thorsten Peters $^{\mathrm{b}}$ \\ Karin Scharffetter-Kochanek ${ }^{b}$ Barbara Walzog $^{a}$ \\ ${ }^{a}$ Department of Physiology, Ludwig Maximilians University, Munich, and ${ }^{\mathrm{b}}$ Department of Dermatology and \\ Allergic Diseases, University of UIm, UIm, Germany
}

\section{Key Words}

Inflammation-mediated angiogenesis .

Neovascularization · Polymorphonuclear neutrophils ·

Wound repair

\begin{abstract}
Growing evidence supports the concept that polymorphonuclear neutrophils (PMN) are critically involved in inflammation-mediated angiogenesis which is important for wound healing and repair. We employed an oligonucleotide microarray technique to gain further insight into the molecular mechanisms underlying the proangiogenic potential of human PMN. In addition to 18 known angiogenesis-relevant genes, we detected the expression of 10 novel genes, namely midkine, erb-B2, ets- 1 , transforming growth factor receptor- $\beta_{2}$ and $-\beta_{3}$, thrombospondin, tissue inhibitor of metalloproteinase 2 , ephrin A2, ephrin B2 and restin in human PMN freshly isolated from the circulation. Gene expression was confirmed by the RT-PCR technique. In vivo evidence for the role of PMN in neovascularization was provided by studying neovascularization in a skin model of wound healing using CD18-deficient mice which lack PMN infiltration to sites of lesion. In CD18-deficient animals, neo-
\end{abstract}

vascularization was found to be significantly compromised when compared with wild-type control animals which showed profound neovascularization within the granulation tissue during the wound healing process. Thus, PMN infiltration seems to facilitate inflammationmediated angiogenesis which may be a consequence of the broad spectrum of proangiogenic factors expressed by these cells.

Copyright (C) 2006 S. Karger AG, Basel

\section{Introduction}

Human polymorphonuclear neutrophils (PMN) are well known to play an important role in host defense and inflammation. During the acute inflammatory response, the PMN extravasate from the blood into the tissue, where they exert their defense functions. However, growing evidence supports the concept that PMN also contribute to inflammation-mediated angiogenesis, which is a critical step in the process of wound healing and repair. PMN secrete a variety of soluble mediators, including interleukin 8 (IL-8) [1]. IL-8 is an important proinflammatory mediator [2], but as well as other cytokines, it is also able to induce angiogenesis [3]. In addition, PMN

\section{KARGER}

Fax +4161306 1234 E-Mail karger@karger.ch www.karger.com (c) 2006 S. Karger AG, Basel

1018-1172/06/0431-0001\$23.50/0

Accessible online at:

www.karger.com/jvr
Prof. Dr. Barbara Walzog

Department of Physiology, Ludwig-Maximilians-Universität München

Schillerstrasse 44

DE-80336 München (Germany)

Tel. +49 89218075 414, Fax +49 89218075 396, E-Mail walzog@lrz.uni-muenchen.de 
secrete the proangiogenic hepatocyte growth factor [4, 5] and the vascular endothelial growth factor (VEGF) [6], one of the most important activators of angiogenesis [7]. As PMN accumulate in high number at sites of lesion, their ability to release different proangiogenic mediators suggests a putative role of PMN in inflammation-mediated angiogenesis.

In vivo evidence for the role of PMN in inflammationmediated angiogenesis and wound repair was provided by the observation that CXCR2-deficient mice, which lacked PMN infiltration in the thioglycollate-induced peritonitis [8], showed delayed angiogenesis and, moreover, impaired cutaneous wound healing [9]. IL- 8 is known to bind to CXCR2 on endothelial cells and to induce angiogenesis [10]. In vivo, PMN represent the main source of macrophage inflammatory protein 2 , the murine homolog of human IL-8 [11]. Accordingly, a recent study has demonstrated a role of macrophage inflammatory protein 2 and VEGF in PMN-mediated angiogenesis in mice [12].

Further evidence for the involvement of PMN in IL8-mediated angiogenesis was obtained in a study demonstrating that the angiogenic response upon IL-8 treatment was absent in neutropenic animals [13]. Thus, the linkage of inflammation, angiogenesis and wound healing may at least in part result from the multifunctional role of proinflammatory cytokines, e.g. IL-8. However, tumor necrosis factor (TNF)- $\alpha$, which is released by PMN upon activation [14], seems to represent another factor that is involved in PMN-mediated angiogenesis. TNF- $\alpha$ has been shown to induce IL-8, VEGF and basic fibroblast growth factor expression in microvascular endothelial cells and neutralizing antibodies against IL-8, and VEGF blocked TNF- $\alpha$-induced neovascularization [15]. Moreover, we have recently shown that the conditioned media derived from activated human PMN induced the sprouting of capillary-like structures in vitro [16], showing that human PMN have the ability to directly induce angiogenesis. Thus, accumulating evidence demonstrated an important role of PMN in angiogenesis, but the full spectrum of PMN-derived proangiogenic factors remained elusive. Therefore, we employed the microarray technique to delineate the full molecular basis of the proangiogenic potential of human PMN. The impact of PMN in inflammation-mediated angiogenesis was studied in a skin model of wound healing using CD18-deficient animals which lack PMN infiltration to sites of lesion due to the absence of leukocyte adhesion molecules of the $\beta_{2^{-}}$ integrin family (CD11/CD18) [17].
Table 1. Supplementary data showing the relative expression of angiogenesis-relevant genes in human PMN

\begin{tabular}{|c|c|c|c|c|}
\hline \multirow[t]{3}{*}{ Gene } & \multicolumn{4}{|c|}{ Relative gene expression } \\
\hline & \multicolumn{2}{|c|}{ microarray lot 1906} & \multicolumn{2}{|c|}{ microarray lot 0507} \\
\hline & array 1 & array 2 & array 3 & array 4 \\
\hline uPA & n.d. & 0.02 & 0.32 & 0.23 \\
\hline erb-B2 ${ }^{1}$ & 0.08 & 0.05 & 0.42 & 0.33 \\
\hline $\mathrm{T} \beta \mathrm{RI}$ & 0.03 & n.d. & 0.36 & 0.31 \\
\hline TGF- $\beta_{1}$ & 0.14 & 0.08 & 0.35 & 0.42 \\
\hline TIMP-1 & 0.10 & n.d. & 0.34 & 0.35 \\
\hline VEGF & n.d. & 0.06 & 0.33 & 0.41 \\
\hline Ephrin A $2^{1}$ & 0.10 & n.d. & 0.45 & 0.33 \\
\hline Ephrin $B 2^{1}$ & 0.08 & n.d. & 0.46 & 0.35 \\
\hline$\beta_{3}$-Integrin subunit & n.d. & 0.31 & n.d. & 0.30 \\
\hline GRO- $\alpha$ & 0.27 & 0.29 & 0.43 & 0.27 \\
\hline CHGA & 0.20 & 0.42 & 0.42 & 0.31 \\
\hline THBS- $3^{1}$ & n.d. & 0.31 & n.d. & 0.39 \\
\hline TGF- $\alpha$ & 0.24 & n.d. & 0.44 & 0.42 \\
\hline TIMP-21 & 0.31 & 0.14 & 0.70 & 0.35 \\
\hline Restin $^{1}$ & 0.27 & 0.36 & 0.43 & 0.49 \\
\hline VE-cadherin $^{1}$ & 0.32 & 0.57 & 0.43 & 0.29 \\
\hline MMP-9 & 0.27 & 0.16 & 0.68 & 0.52 \\
\hline PECAM-1 & 0.52 & 0.18 & 0.50 & 0.53 \\
\hline ets- $1^{1}$ & n.d. & 0.49 & n.d. & 0.39 \\
\hline HIF- $1 \alpha$ & 0.63 & 0.42 & 0.68 & 0.36 \\
\hline TNF- $\alpha$ & 0.31 & 0.37 & 1.10 & 0.39 \\
\hline $\mathrm{T} \beta \mathrm{RII}^{1}$ & 0.37 & n.d. & 0.93 & 0.35 \\
\hline Cox-2 & 0.86 & 0.30 & 0.71 & 0.41 \\
\hline $\mathrm{MDK}^{1}$ & 0.48 & 0.34 & 1.03 & 0.44 \\
\hline$\alpha_{5}$-Integrin subunit & 0.28 & n.d. & 0.97 & n.d. \\
\hline HPSE & 0.39 & 0.25 & 1.44 & 0.43 \\
\hline IL-8 & 1.76 & 0.91 & 1.95 & 0.50 \\
\hline T $\beta \mathrm{RIII}^{1}$ & 2.55 & 0.54 & 1.59 & 0.45 \\
\hline
\end{tabular}

Gene expression was measured using the oligonucleotide microarray technique (GEarray kit for angiogenesis-relevant genes, catalogue number HS-009N-4; SuperArray) in human PMN freshly isolated from the circulation. Microarrays with two different lot numbers were used. Gene expression normalized for the expression of $\beta$-actin. Data represent relative OD measured in PMN from 4 different individuals. n.d. $=$ Not detected .

${ }^{1}$ Genes previously unknown to be expressed in PMN.

\section{Materials and Methods}

\section{Reagents}

Phosphate-buffered saline (PBS) was obtained from Biochrom, Berlin, Germany, agarose was provided by GibcoBRL, Eggenstein, Germany, and DNA markers (100-bp DNA ladder) were obtained from MBI Fermentas, St. Leon-Rot, Germany. Glucose and Percoll were obtained from Sigma, Deisenhofen, Germany, Liquemin 2500 (heparin) was purchased from Hoffmann-La Roche, Grenzach-Wyhlen, Germany, and all other reagents and chemicals were 
Fig. 1. Genes previously unknown to be expressed in PMN are indicated by black bars. Gene expression was defined 'positive' when detected by microarrays from both lot numbers in at least 2 of 4 different individuals tested. The obtained data were normalized using the expression of $\beta$-actin. Data represent mean relative OD $\pm \mathrm{SD}$.

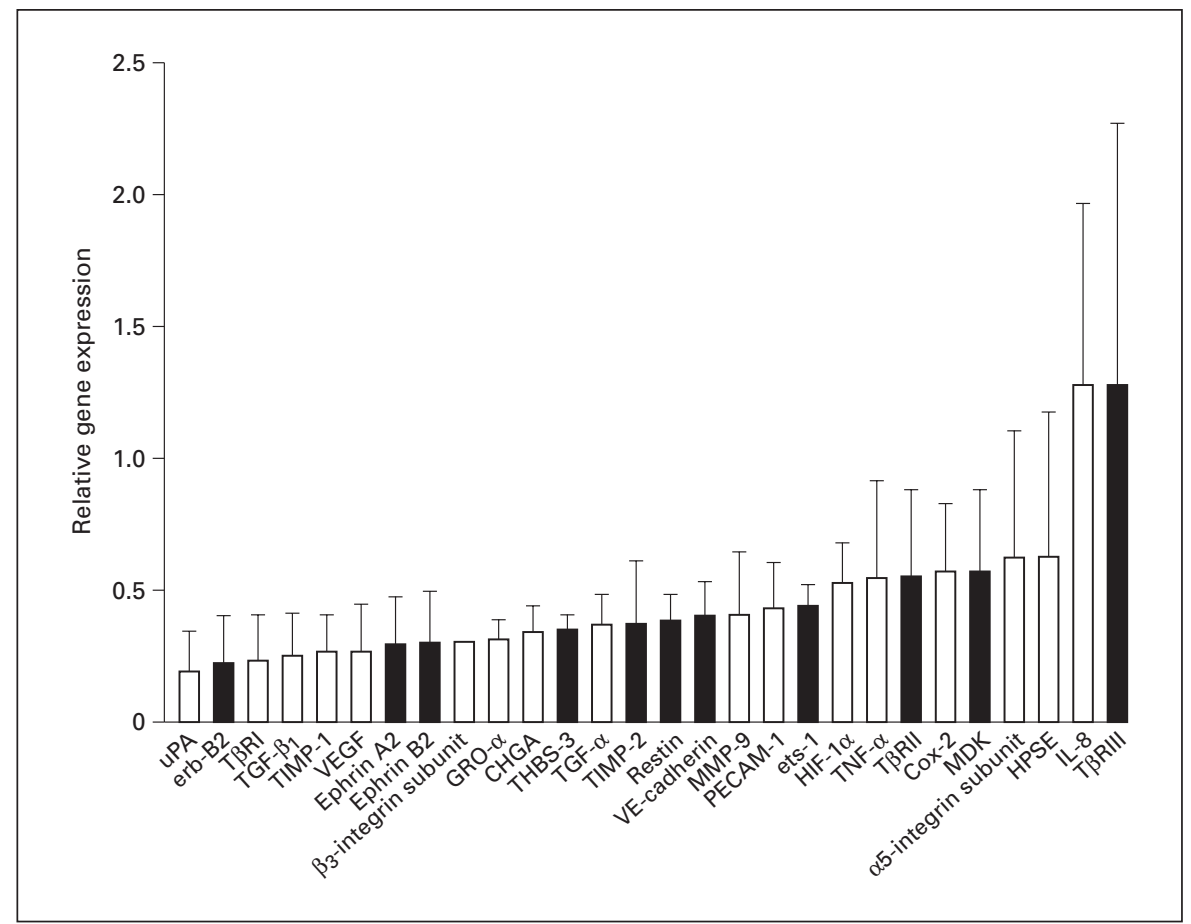

purchased from Merck, Darmstadt, Germany, and Serva, Heidelberg, Germany.

\section{Isolation of Human PMN}

PMN were isolated from heparinized blood $(10 \mathrm{IU} / \mathrm{ml})$ of healthy adult volunteers, according to the institutional guidelines of the Ludwig Maximilians University, Munich, Germany. After erythrocyte sedimentation in the presence of $40 \%(\mathrm{v} / \mathrm{v})$ autologous plasma for $1 \mathrm{~h}$, the leukocyte-rich plasma was layered onto a discontinuous Percoll gradient as previously described [18] and centrifuged at $600 \mathrm{~g}$ for $20 \mathrm{~min}$. The PMN-containing layer was collected and washed in Dulbecco's PBS. PMN viability was $>99 \%$, as assessed by the trypan blue exclusion test; purity was $>99 \%$, as analyzed by microscopy using Haemacolor staining (Merck).

\section{Gene Array}

The human GEarray kit for angiogenesis-relevant genes (catalogue number HS-009N-4, lot numbers 1906 and 0507; SuperArray, Bethesda, Md., USA) was used to characterize the gene expression profiles of human neutrophils freshly isolated from the circulation of 4 different donors (the complete gene list can be obtained on the Internet at http://www.superarray.com). Total RNA was isolated from the neutrophils by the guanidine isothiocyanate method [19] using TRI Reagent (Sigma). The array was performed according to the manufacturer's instructions. Briefly, probe synthesis was performed for $120 \mathrm{~min}$ at $42^{\circ} \mathrm{C}$ using RNA $(3 \mu \mathrm{g})$ and $100 \mathrm{U}$ reverse transcriptase (Promega, Madison, Wisc., USA), 8 U RNase inhibitor (Promega), a dNTP mix with biotin-16-dUTP (Roche Molecular Biochemicals, Penzberg, Germany) and a primer mix. After prehybridization for $1 \mathrm{~h}$ at $60^{\circ} \mathrm{C}$ with GEAhyb hybridization solution containing $100 \mu \mathrm{g} / \mathrm{ml}$ heat-denatured salmon sperm DNA
(Stratagene, La Jolla, Calif., USA), the filters were hybridized overnight at $60^{\circ} \mathrm{C}$ with the heat-denatured biotinylated cDNA probes. After two extensive washes, the filters were incubated with alkaline phosphatase-conjugated streptavidin and gene expression was detected by chemiluminescence using the alkaline phosphatase substrate CDP-Star and exposure to X-ray films (XOMAT-AR, Kodak, Germany). Data were analyzed using the GEarray Analyzer program (http://www.superarray.com). A blank was used for background subtraction, and data were normalized using $\beta$-actin expression. The relative gene expression is shown in the supplementary data (table 1, fig. 1). The data were obtained from microarrays with two different lot numbers. Gene expression was defined 'positive' when detected by microrrays from both lot numbers in at least 2 of 4 individuals tested.

\section{Reverse Transcription and Polymerase Chain Reaction}

The expression of genes that was found to be positive using the microarray technique was verified by RT-PCR analysis. Total RNA was isolated from human PMN as described above. Subsequently, RNA $(2 \mu \mathrm{g})$ was reverse transcribed into cDNA using oligo(dT) $)_{15}$ primers (Promega, Mannheim, Germany) and 200 U reverse transcriptase Moloney murine leukemia virus (Promega). PCR amplification was carried out using specific primer sets (Metabion, Munich, Germany) (table 2) and 0.25 U Taq DNA polymerase (Promega). PCR products were analyzed by agarose gel electrophoresis and visualized with ethidium bromide under UV light. For each gene, the RT-PCR was carried out using PMN obtained from at least 3 different individuals. With the exception of vascular/endothelial (VE)cadherin, the RT-PCR for all genes that were defined 'positive' by microarray analysis gave a positive result with all donors tested. For VE-cadherin, all donors showed a negative result in the RT-PCR. 
Table 2. Specific primer sets

\begin{tabular}{|c|c|c|c|}
\hline Gene & Primer & Product, bp & PCR \\
\hline$\beta$-Actin & $\begin{array}{l}\text { u: TGTCCACCTTCCAGCAGATGTG } \\
\text { d: AGTCCTCGGCCACATTGTGAAC }\end{array}$ & 300 & 21 cycles: $60 \mathrm{~s} 94^{\circ} \mathrm{C}, 60 \mathrm{~s} 59^{\circ} \mathrm{C}, 60 \mathrm{~s} 72^{\circ} \mathrm{C}$ \\
\hline Ephrin A2 & $\begin{array}{l}\text { u: GCGTGAAGAGCTGGAAC } \\
\text { d: TACGCCGTCTACTGGAAC }\end{array}$ & 294 & 40 cycles: $60 \mathrm{~s} 94^{\circ} \mathrm{C}, 60 \mathrm{~s} 55^{\circ} \mathrm{C}, 60 \mathrm{~s} 72^{\circ} \mathrm{C}$ \\
\hline Ephrin B2 & $\begin{array}{l}\text { u: GAAGGGACTCCGTGTGGAAG } \\
\text { d: CTGGTTTGGCACAGTTGAGG }\end{array}$ & 303 & $\begin{array}{l}11 \text { cycles: } 60 \mathrm{~s} 94^{\circ} \mathrm{C}, 120 \mathrm{~s} \text { increment } 59-64^{\circ} \mathrm{C}, 60 \mathrm{~s} 72^{\circ} \mathrm{C} \\
31 \text { cycles: } 60 \mathrm{~s} 94^{\circ} \mathrm{C}, 60 \mathrm{~s} 60^{\circ} \mathrm{C}, 60 \mathrm{~s} 72^{\circ} \mathrm{C}\end{array}$ \\
\hline erb-B2 & $\begin{array}{l}\text { u: GGAAGTACACGATGCGGAGA } \\
\text { d: GCCATCACGTATGCTTCGTC }\end{array}$ & 277 & 35 cycles: $60 \mathrm{~s} 94^{\circ} \mathrm{C}, 60 \mathrm{~s} 59^{\circ} \mathrm{C}, 60 \mathrm{~s} 72^{\circ} \mathrm{C}$ \\
\hline ets-1 & $\begin{array}{l}\text { u: GAATGACTACCCCTCGGTCA } \\
\text { d: TTGGTCCACTGCCTGTGTAG }\end{array}$ & 398 & 25 cycles: $60 \mathrm{~s} 94^{\circ} \mathrm{C}, 60 \mathrm{~s} 59^{\circ} \mathrm{C}, 60 \mathrm{~s} 72^{\circ} \mathrm{C}$ \\
\hline HIF- $1 \alpha$ & $\begin{array}{l}\text { u: TCCTTCTCTTCTCCGCGTGT } \\
\text { d: GTGGCAACTGATGAGCAAGC }\end{array}$ & 231 & 26 cycles: $60 \mathrm{~s} 94^{\circ} \mathrm{C}, 60 \mathrm{~s} 59^{\circ} \mathrm{C}, 60 \mathrm{~s} 72^{\circ} \mathrm{C}$ \\
\hline MDK & $\begin{array}{l}\text { u: AATGCTCAGTGCCAGGAGAC } \\
\text { d: AGCTTCCCAGAATCCCTTGT }\end{array}$ & 299 & 40 cycles: $60 \mathrm{~s} 94^{\circ} \mathrm{C}, 60 \mathrm{~s} 61^{\circ} \mathrm{C}, 60 \mathrm{~s} 72^{\circ} \mathrm{C}$ \\
\hline Restin & $\begin{array}{l}\text { u: TCTTGGGGAGACCGACTTTG } \\
\text { d: TGCTGCTGCTTCTCCTTCAG }\end{array}$ & 399 & 32 cycles: $60 \mathrm{~s} 94^{\circ} \mathrm{C}, 60 \mathrm{~s} 60^{\circ} \mathrm{C}, 60 \mathrm{~s} 72^{\circ} \mathrm{C}$ \\
\hline T $\beta$ RII & $\begin{array}{l}\text { u: CCTAACCTGCTGCCTGTGTG } \\
\text { d: CGTTGTCCTTCATGCTTTCG }\end{array}$ & 302 & 32 cycles: $60 \mathrm{~s} 94^{\circ} \mathrm{C}, 60 \mathrm{~s} 60^{\circ} \mathrm{C}, 60 \mathrm{~s} 72^{\circ} \mathrm{C}$ \\
\hline TßRIII & $\begin{array}{l}\text { u: AGTGTGTGCCTCCTGACGAA } \\
\text { d: ACTTGCTGCCTTCCTGCTGT }\end{array}$ & 298 & 28 cycles: $60 \mathrm{~s} 94^{\circ} \mathrm{C}, 60 \mathrm{~s} 59^{\circ} \mathrm{C}, 60 \mathrm{~s} 72^{\circ} \mathrm{C}$ \\
\hline THBS-3 & $\begin{array}{l}\text { u: GGCTGTGACCCAAACTCCAT } \\
\text { d: TTCTTGATCCCATCCCCATC }\end{array}$ & 401 & $\begin{array}{l}11 \text { cycles: } 60 \mathrm{~s} 94^{\circ} \mathrm{C}, 120 \mathrm{~s} \text { increment } 55-60^{\circ} \mathrm{C}, 60 \mathrm{~s} 72^{\circ} \mathrm{C} \\
28 \text { cycles } 60 \mathrm{~s} 94^{\circ} \mathrm{C}, 60 \mathrm{~s} 58^{\circ} \mathrm{C}, 60 \mathrm{~s} 72^{\circ} \mathrm{C}\end{array}$ \\
\hline TIMP-2 & $\begin{array}{l}\text { u: CTCGGCAGTGTGTGGGGTC } \\
\text { d: CGAGAAACTCCTGCTTGGGG }\end{array}$ & 364 & 25 cycles: $60 \mathrm{~s} 94^{\circ} \mathrm{C}, 60 \mathrm{~s} 59^{\circ} \mathrm{C}, 60 \mathrm{~s} 72^{\circ} \mathrm{C}$ \\
\hline VE-cadherin $^{1}$ & $\begin{array}{l}\text { u: ACCGGATGACCAAGTACAGC } \\
\text { d: ACACACTTTGGGCTGGTAGG }\end{array}$ & 596 & 35 cycles: $60 \mathrm{~s} 94^{\circ} \mathrm{C}, 60 \mathrm{~s} 59^{\circ} \mathrm{C}, 60 \mathrm{~s} 72^{\circ} \mathrm{C}$ \\
\hline VE-cadherin $^{2}$ & $\begin{array}{l}\text { u: ACGAAAAGCTTGGACCGAGA } \\
\text { d: TCAATGGTGAAAGCGTCCTG }\end{array}$ & 293 & 35 cycles: $60 \mathrm{~s} 94^{\circ} \mathrm{C}, 60 \mathrm{~s} 59^{\circ} \mathrm{C}, 60 \mathrm{~s} 72^{\circ} \mathrm{C}$ \\
\hline VE-cadherin ${ }^{3}$ & $\begin{array}{l}\text { u: ATGCTCCTCGCCACATC } \\
\text { d: ACAACCGATGCGTGAAC }\end{array}$ & 450 & 35 cycles: $60 \mathrm{~s} 94^{\circ} \mathrm{C}, 60 \mathrm{~s} 59^{\circ} \mathrm{C}, 60 \mathrm{~s} 72^{\circ} \mathrm{C}$ \\
\hline
\end{tabular}

The specific primer sets were used at a final concentration of $0.2 \mu M$ each. PCR cycles were followed by incubation for 5 min at $72^{\circ} \mathrm{C}$ for elongation of PCR products. Increment: annealing was performed with an increment of $0.5^{\circ} \mathrm{C}$ per cycle. $\mathrm{u}=\mathrm{Upstream}$ primer; $\mathrm{d}=$ downstream primer. For the detection of the VE-cadherin mRNA, three different primer sets for VE-cadherin ${ }^{1-3}$ were used which all gave negative results.

Mice

CD18-/- homozygotes [17] and CD18+/+ wild-type controls were derived from heterozygote crosses on a mixed $129 \mathrm{~Sv} \times$ C57BL/6 background. Animals were constantly maintained under specific pathogen-free conditions. Wound healing studies were performed using mice at the age of 8-12 weeks. All experiments were institutionally approved and done in accordance with the German Law for Welfare of Laboratory Animals.
Wound Healing Model

Prior to injury, mice were anaesthetized by intraperitoneal injection of a solution ( $250 \mu \mathrm{l} / 25 \mathrm{~g}$ body weight) containing ketamine $(10 \mathrm{~g} / \mathrm{l})$ and xylazine $(8 \mathrm{~g} / \mathrm{l})$. After shaving the dorsal hair and cleaning the exposed skin with $70 \%$ ethanol, full thickness (including the panniculus carnosus) excisional wounds were punched at two sites in the middle of the dorsum using 5-mm biopsy stamps (Stiefel, Offenbach, Germany). Wounds were left uncovered and were excised 5 days after induction of injury. For the preparation of cryo- 
sections, wounds were embedded in Tissue-Tek OCT ${ }^{\circledR}$ compound (Fisher Scientific, Bridgewater, N.J., USA) and immediately frozen in liquid nitrogen.

\section{Immunofluorescence Histology}

Methanol-fixed frozen sections $(5 \mu \mathrm{m})$ from the middle of the wound were incubated for $1 \mathrm{~h}$ with the rat anti-mouse CD31 antibody (BD Biosciences Pharmingen/BD Bioscience, Heidelberg, Germany) in PBS containing 1\% BSA. After three washes for 10 min in PBS, sections were incubated for $1 \mathrm{~h}$ with the secondary cyanine 2-conjugated anti-rat antibody (Dianova, Hamburg, Germany), washed again, mounted with Mowiol (Dako, Hamburg, Germany) and analyzed by fluorescence microscopy using an Axioscop 2 microscope (Zeiss, Oberkochen, Germany) supported by AxioVison ${ }^{\circledR}$ software (Zeiss).

\section{Statistical Analysis}

Statistical significance was determined using the Mann-Whitney U test. Differences were considered to be statistically significant at values of $\mathrm{p}<0.005$.

\section{Results}

In order to elucidate the molecular basis for the proangiogenic potential of human PMN, we used an oligonucleotide microarray technique to identify angiogenesis-relevant genes in these cells. Using this approach, we screened 96 angiogenesis-relevant genes in human PMN, freshly isolated from the circulation. We detected the expression of 28 genes. As shown in detail in table 3, these genes include different cytokines, namely IL-8, growthrelated oncogene-alpha (GRO- $\alpha)$, midkine (MDK), transforming growth factor- $\beta_{1}$ (TGF- $\left.\beta_{1}\right)$, TNF- $\alpha$ and VEGF. Whereas IL- 8 , GRO- $\alpha$, TGF- $\beta_{1}$, TNF- $\alpha$ and VEGF are well known to be expressed in human PMN, this was the first demonstration of MDK expression. Therefore, we employed the RT-PCR technique to verify this result (fig. 2). Using this approach, we were able to detect MDK at the RNA level confirming the expression of this novel chemokine in human PMN.

In addition, the microarray technique revealed the mRNA expression of three angiogenesis-relevant transcription factors in human PMN, namely erb-B2, ets-1 and hypoxia-inducible factor 1 alpha $(\mathrm{HIF}-1 \alpha)$. Whereas human PMN were already known to express HIF-1 $\alpha$, this was the first description for erb-B2 and ets-1 expression in human PMN. Subsequently, we were able to confirm this result by the RT-PCR technique (fig. 2). Among the cell surface receptors, we showed that human PMN not only express the TGF- $\beta$ type I receptor (T $\beta$ RI), but also the TGF- $\beta$ type II (T $\beta$ RII) and type III receptors (T $\beta$ RIII). These observations were confirmed by the RT-PCR tech-
Table 3. Angiogenesis-relevant genes expressed in freshly isolated $\mathrm{PMN}$ as delineated by the microarray technique

\begin{tabular}{llc}
\hline Gene & Other names & Reference \\
\hline Cytokines & & \\
IL-8 & CXCL8 & 1 \\
GRO- $\alpha$ & CXCL1 & 20 \\
MDK $^{1}$ & neurite growth-promoting & \\
& factor 2 & 21 \\
TGF- $\beta_{1}$ & & 14 \\
TNF- $\alpha$ & & 6 \\
VEGF & &
\end{tabular}

Transcription factors

erb-B2 ${ }^{1}$ neu, HER-2

ets- $1^{1}$

$\mathrm{HIF}-1 \alpha$

Cytokine receptors

T $\beta$ RI

T $\beta$ RII $^{1}$

T $\beta$ RIII $^{1}$

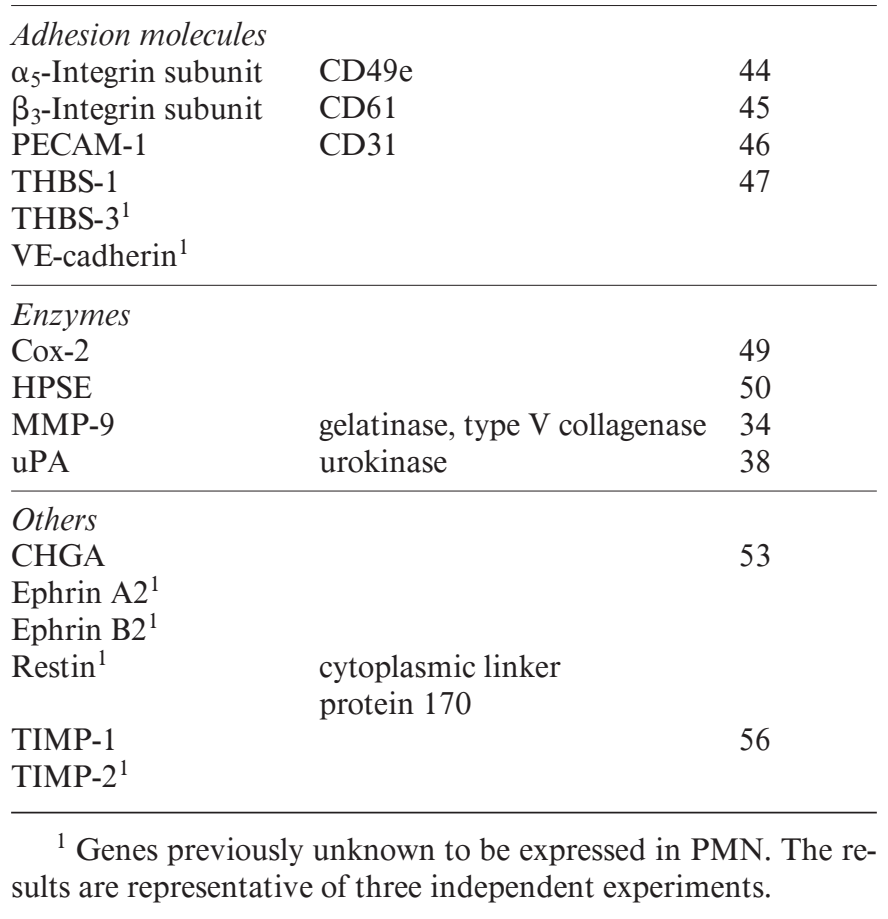

nique. Furthermore, we detected the expression of the known adhesion molecules CD49e, CD61, CD31 and thrombospondin (THBS)-1 in human PMN. However, the expression of the unknown genes THBS-3 and VEcadherin was also detectable by means of the microarray technique. We were able to confirm the expression of THBS-3 by means of the RT-PCR technique. However, 


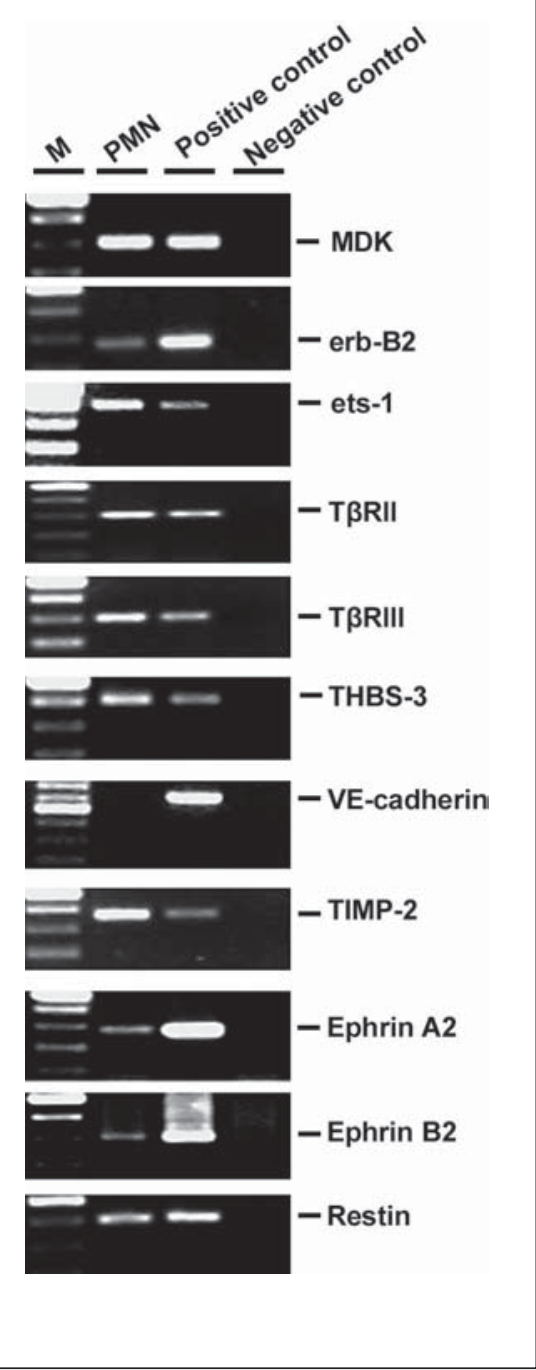

Fig. 2. Novel angiogenesis-relevant genes in human $P M N$, as delineated by the RT-PCR technique. RT-PCR analyses of RNA obtained from freshly isolated PMN, positive control or negative control (without template) were performed using specific primer sets and amplification protocols as shown in table 2. The specific PCRDNA fragments were separated by agarose gel electrophoresis and visualized by ethidium bromide staining under UV light. We were also able to detect the expression of hepatocyte growth factor in human PMN using the RT-PCR technique (data not shown) which was not included in the microarray analysis. Three different primer sets for VE-cadherin were used which all gave a positive result in human umbilical endothelial cells used as control. However, all three primer sets failed to amplify a VE-cadherin-specific fragment in human PMN (results for primer set VE-cadherin ${ }^{1}$ are shown in table 2). $\mathrm{M}=$ marker. All results are representative of three independent experiments. we were unable to demonstrate VE-cadherin expression in PMN using this approach, although three different primer sets were used and positive results were obtained from human umbilical vein endothelial cells indicating that the primer sets were functional. This suggests that the microarray gave a false-positive result in the case of VE-cadherin.

Moreover, we confirmed the expression of four wellknown angiogenesis-relevant enzymes, namely cyclooxigenase 2 (Cox-2), heparanase (HPSE), matrix metalloproteinase (MMP)-9 and the urokinase-type plasminogen activator ( $\mathrm{UPA}$ ) in human PMN by the microarray technique. Furthermore, we detected the expression of the known angiogenesis-relevant genes tissue inhibitor of metalloproteinase (TIMP)-1 and chromagranin A (CHGA) in human PMN. In addition, we found the expression of four novel genes in human PMN, i.e. TIMP-2, ephrin A2, ephrin $\mathrm{B} 2$ and restin using the microarray technique, and we were able to confirm this finding by the RT-PCR technique (fig. 2). Taken together, we detected a total of 28 angiogenesis-relevant genes in human PMN including 11 novel genes by the microarray technique, namely MDK, erb-B2, ets-1, T $\beta$ RII, T $\beta$ RIII, THBS-3, VE-cadherin, ephrin A2, ephrin B2, restin and TIMP-2. With the exception of VE-cadherin, we were able to confirm the expression of all genes at the RNA level using the RT-PCR technique.

In order to study the impact of PMN for inflammation-mediated angiogenesis, neovascularization was studied in a skin model of wound healing using CD18-/- mice and wild-type control animals. As CD18-/- mice lack the expression of $\beta_{2}$-integrins (CD11/CD18), which are critical for PMN extravasation, the CD18-/- mice show virtually no PMN infiltration to sites of skin lesion, whereas wild-type animals demonstrate a robust PMN infiltration of wounded skin [17]. At day 5 after the induction of injury, we measured neovascularization in the wound beds using CD31 staining of blood vessels and detected a profound neovascularization in the granulation tissue of wild-type animals which is well known to be typical and important for the normal wound healing process (fig. 3a). In contrast, CD18-/- animals that lack PMN infiltration to sites of wounded skin showed a severely diminished vessel density within the granulation tissue at the same time point. This result was confirmed by counting the vessels under the microscope (fig. 3b). The median number of CD31-positive vessels per high-power field was 159 (range 114-185) in wound beds of wild-type animals and 105 (range 0-148) in CD18-/- animals $(\mathrm{p}<0.005)$. Thus, the absence of profound PMN infiltration during the 



wound healing process of CD18-/- animals was associated with an impairment of neovascularization within the granulation tissue suggesting a role of PMN in inflammation-mediated angiogenesis.

\section{Discussion}

Neovascularization by sprouting angiogenesis is critical for wound healing and repair. We have recently shown that PMN have the ability to directly induce angiogenesis in vitro suggesting a role of these cells for the induction of inflammation-mediated angiogenesis [16]. In order to delineate the molecular basis of this effect, the present study was undertaken to identify angiogenesis-relevant genes in these cells. By means of the microarray tech-

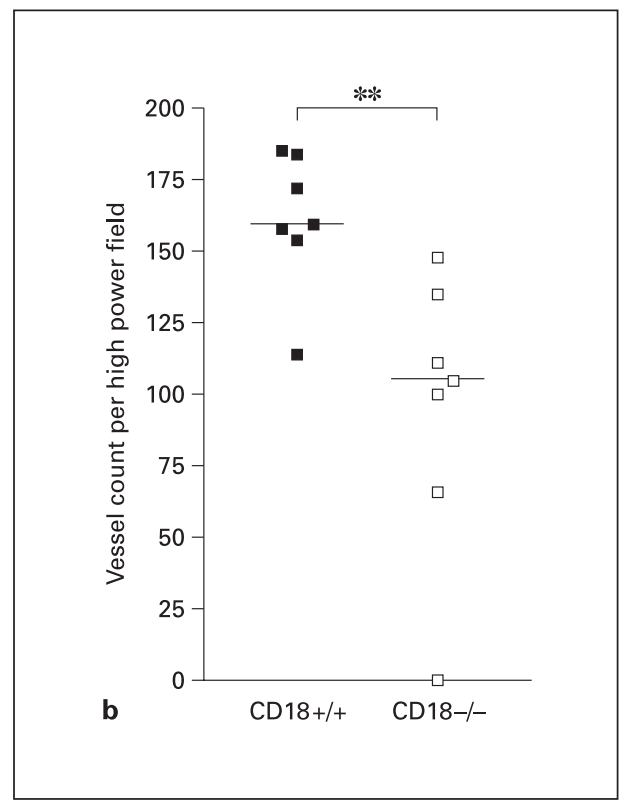

Fig. 3. Diminished vascularization of wound beds in CD18-/mice. Cryosections of wound sites from CD18-/- and wild-type mice (CD18+/+) at day 5 after induction of injury. Immunofluorescence staining was performed with the rat anti-mouse CD31 monoclonal antibody and a secondary cyanine 2-conjugated antibody. a Sections showing the most significant differences of CD31 staining in each cohort $(n=4)$ are shown. The broken line indicates the border between eschar (esc) and mesenchymal restoration tissue (dermis). Scale bar $=200 \mu \mathrm{m}$. b Vessels staining positive for CD31 were counted in each high-power field. There was no difference in the vessel density of uninjured skin surrounding the wounds between CD18-/- and wild-type mice (data not shown). Similar results were obtained from three independent investigators. Bars indicate the media of each cohort. ${ }^{* *} \mathrm{p}<0.005$.

nique, we detected the mRNA expression of 28 genes, including five known cytokines, namely IL- 8 , GRO- $\alpha$, TGF- $\beta$, TNF- $\alpha$ and VEGF $[1,6,14,20,21]$. In addition, we identified MDK, a novel chemokine, in human PMN. All of the detected cytokines have been reported to act as proangiogenic mediators. This is especially true for VEGF and IL- $8[7,12,13,16]$, but also for GRO- $\alpha$, TGF- $\beta$ and TNF- $\alpha$ which have been demonstrated to serve as proangiogenic factors in different models [15, 22, 23].

The newly identified cytokine MDK has been reported to induce the mobilization of intracellular calcium by a $G$ protein-coupled mechanism and it induces chemotaxis of human PMN [24, 25]. In vivo evidence for a role of MDK in PMN infiltration was demonstrated in a study using MDK-deficient mice, in which the numbers of infiltrating neutrophils were reduced compared with wild- 
type control animals in a model of renal ischemic reperfusion injury [26]. Moreover, MDK has been found to induce angiogenesis in the rabbit corneal assay [27]. Similar studies have demonstrated a role of MDK in tumor progression by promoting angiogenesis in bladder cancer [28], and MDK expression has been shown to correlate with the poor outcome of patients with invasive cancers [29], suggesting that MDK acts as an activator of tumor angiogenesis. As we have identified MDK expression in human PMN, it suggests a novel role of this chemokine in inflammation-mediated angiogenesis.

Beside the expression of HIF-1 $\alpha$ which is well known to induce for example VEGF [30, 31], we detected the expression of two novel angiogenesis-relevant transcription factors in human PMN, namely erb-B2 and ets-1. The tyrosine kinase erb-B2 acts as a transcriptional activator of the Cox-2 promotor [32], which upregulates VEGF expression via prostaglandin $\mathrm{E}_{2}$-mediated HIF- $1 \alpha$ induction [31]. The transcription factor ets- 1 is a target gene of HIF- $1 \alpha$ [31] and induces the expression of different MMPs, including MMP-9 [33]. MMP-9 is expressed by human PMN [34], activates TGF- $\beta_{1}[35]$ and promotes angiogenesis by degrading extracellular matrix proteins [36]. Moreover, ets-1 stimulates angiogenesis by upregulating the expression of uPA [37]. This protease is expressed by PMN [38] and is known to activate TGF- $\beta$ and MMP-9 by proteolytic cleavage [35, 36].

In addition to T $\beta R I$ [39], we identified T $\beta R I I$ and T $\beta R I I I$ in human PMN, the latter of which is induced by HIF-1 $\alpha$ [31]. This is of interest because low doses of TGF- $\beta$ were found to promote angiogenesis [40], and mice deficient in T $\beta R I$, T $\beta$ RII or T $\beta$ RIII show severe defects in vasculogenesis and/or angiogenesis [41]. As TGF- $\beta$ induces the expression of VEGF, MMP-2 and MMP-9 in fibroblasts, endothelial cells and human prostate cancer cell lines [42, 43], the presence of the full set of TGF- $\beta$ receptors in PMN suggests a putative role of TGF- $\beta_{1}$ signaling in activating the proangiogenic potential of this cell type.

We confirmed the expression of different adhesion molecules in human PMN, namely $\alpha_{5}$-integrin, $\beta_{3}$-integrin and platelet endothelial cell adhesion molecule (PECAM) [44-46]. Although their endothelial expression is known to be critical for angiogenesis, their putative angiogenic role in $\mathrm{PMN}$ is rather questionable. Moreover, we detected the known factor THBS-1 [47] and identified the expression of THBS-3 in human PMN. As THBS are known to inhibit angiogenesis [48], this finding suggests that PMN may also have an antiangiogenic potential. Moreover, we detected the expression of VE-cadherin in
PMN using the microarray technique. Although three different primer sets were used, we were unable to reproduce this finding by the RT-PCR technique, suggesting that in this case, the microarray gave a false-positive result.

Among the angiogenesis-relevant enzymes, we detected the expression of four known proteins, i.e. Cox-2, HPSE, MMP-9 and uPA, in human PMN [34, 38, 49, 50]. MMP-9 plays a prominent role in angiogenesis [51], but recent evidence also suggests an involvement of Cox-2 in this process. Accordingly, different nonsteroidal anti-inflammatory drugs acting selectively on Cox-2 were found to downregulate angiogenesis in a broad spectrum of different angiogenesis models leading to the identification of Cox-2 as a target for tumor angiogenesis [52]. As human PMN express erbB-2 which serves as an activator of the Cox-2 promoter [32], this finding may provide a new aspect for the induction of this enzyme in PMN. Furthermore, we confirmed the expression of CHGA, a member of the granin family of acidic secretory proteins, in human PMN [53] and detected the expression of ephrin B2 and ephrin A2, ligands of ephrin receptor tyrosine kinases. Although the endothelial expression of ephrins and their receptors plays a role in angiogenesis [54], their putative function in PMN-mediated angiogenesis is elusive. Moreover, we demonstrated the expression of restin, a $22-\mathrm{kDa}$ fragment of human collagen XV with homology to the angiogenesis inhibitor endostatin, which inhibits migration of endothelial cells [55]. We also detected the expression of TIMP-1 and TIMP-2 which have been reported to serve as inhibitors of angiogenesis $[56,57]$. Thus, we found a total of four antiangiogenic factors (THBS-3, restin, TIMP-1 and TIMP-2), which may imply that PMN not only possess proangiogenic but also antiangiogenic activity. However, TGF- $\beta$ signaling downregulates TIMP expression [35], and the activation of Cox-2 has been recently shown to suppress p53 [58]. As p53 induces the angiogenesis inhibitor THBS- 1 and downregulates HIF- $1 \alpha[31,59]$, the activation of PMN, which leads to the induction of Cox-2 activity, may shift the balance between the pro- and antiangiogenic activities of human PMN towards the proangiogenic potential.

Accordingly, activated human PMN have been shown to directly induce angiogenesis in vitro [16], arguing for a role of these cells in orchestrating the initiation of inflammation-mediated neovascularization during wound repair and tissue remodeling. In contrast to the extravasation of monocytes and lymphocytes, PMN infiltration of several tissues strictly depends on leukocyte adhesion molecules of the $\beta_{2}$-integrin family (CD11/CD18). This is especially true for thioglycollate-induced peritonitis, 


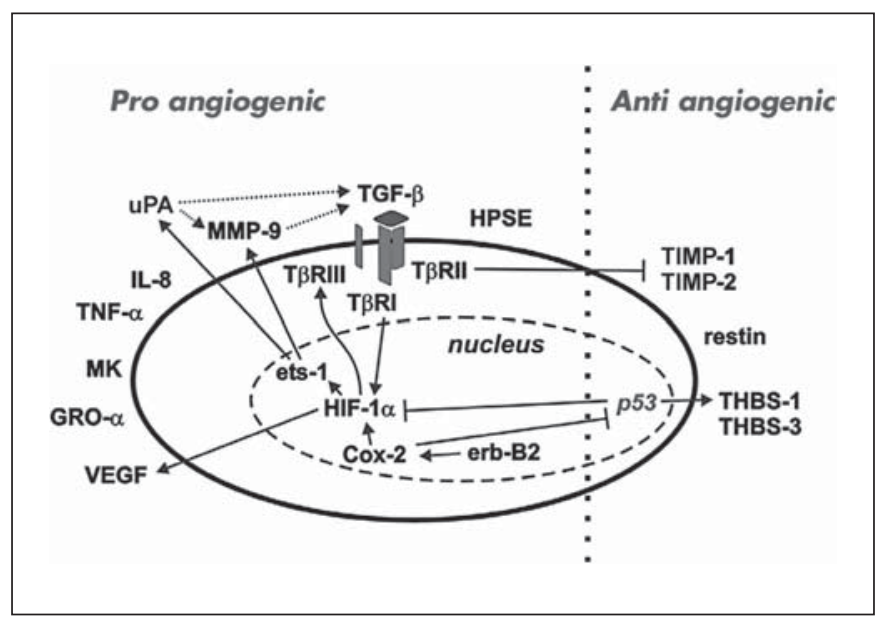

Fig. 4. Schematic overview of angiogenesis-relevant factors in human PMN and their putative cross-talk. Dotted line: activation by proteolytic cleavage.

inflamed cremaster muscle and wounded skin [17, 60]. Accordingly, PMN accumulation at sites of lesion has been shown to be severely compromised in these models $[17,60]$. We now present evidence that the impairment of PMN infiltration in the absence of CD18 was accompanied by a reduction in inflammation-mediated angiogenesis in a skin model of wound healing which provides further evidence for a role of PMN in the induction of inflammation-mediated angiogenesis.

The present findings strongly suggest that not only one, but a variety of different factors may be involved in PMN- mediated generation of functional vessels in vivo. Figure 4 gives an overview of these factors and their putative cross-talk, but it has been taken into consideration that the interpretation of the present data is limited by the measurement of gene expression at the mRNA level. Thus, further investigations are required to prove the functional impact of the factors identified. To date, various proangiogenic approaches are studied in clinical trials [61], but it seems to be a rather optimistic view that the in vivo application of one single factor can induce the formation of functional vessels and an intact microcirculation in vivo. As tumor vessels are highly disorganized and show an abnormal microcirculation [61], it is also questionable whether the identification of the factors responsible for the induction of tumor angiogenesis can provide insight into the mechanisms that are required for the generation of functional microvascular networks in physiological settings; however, inflammation-mediated angiogenesis represents a rare example of functional angiogenesis in the adult. Therefore, the identification of the proangiogenic factors expressed in human PMN may help to unravel the requirements for sustained and functional angiogenesis in vivo.

\section{Acknowledgements}

The expert technical assistance of Mrs. Manuela Haberl and Mrs. Adelheid Hainzl is acknowledged. This study was supported by Deutsche Forschungsgemeinschaft (Wa 1048/1-1 and 1048/1-2, Scha 411/12-1 and SFB 497-C7, Collaborative Research Center, Ulm, Germany).

\section{References}

1 Bazzoni F, Cassatella MA, Rossi F, Ceska M, Dewald B, Baggiolini M: Phagocytosing neutrophils produce and release high amounts of the neutrophil-activating peptide 1/interleukin 8. J Exp Med 1991;173:771-774.

2 Baggiolini M, Walz A, Kunkel SL: Neutrophilactivating peptide-1/interleukin 8 , a novel cytokine that activates neutrophils. J Clin Invest 1989;84:1045-1049.

3 Bernardini G, Ribatti D, Spinetti G, Morbidelli L, Ziche M, Santoni A, Capogrossi MC, Napolitano M: Analysis of the role of chemokines in angiogenesis. J Immunol Methods 2003; 273:83-101.
4 Grenier A, Chollet-Martin S, Crestani B, Izumi H, Ishibashi T, Suzuki H, Kuwano M: Presence of a mobilizable intracellular pool of hepatocyte growth factor in human polymorphonuclear neutrophils. Blood 2002;99:29973004.

5 Grant DS, Kleinman HK, Goldberg ID, Bhargava MM, Nickoloff BJ, Kinsella JL, Polverini P, Rosen EM: Scatter factor induces blood vessel formation in vivo. Proc Natl Acad Sci USA 1993;90:1937-1941.

6 Gaudry M, Brégerie O, Andrieu V, El Benna J, Pocidalo MA, Hakim J: Intracellular pool of vascular endothelial growth factor in human neutrophils. Blood 1997;90:4153-4161.

7 Yancopoulos GD, Davis S, Gale NW, Rudge JS, Wiegand SJ, Holash J: Vascular-specific growth factors and blood vessel formation. Nature 2000;407:242-248.
8 Cacalano G, Lee J, Kikly K, Ryan AM, PittsMeek S, Hultgren B, Wood WI, Moore MW: Neutrophil and B cell expansion in mice that lack the murine IL- 8 receptor homolog. Science 1994;265:682-684.

9 Devalaraja RM, Nanney LB, Qian Q, Du J, Yu Y, Devalaraja MN, Richmond A: Delayed wound healing in CXCR2 knockout mice. J Invest Dermatol 2000;115:234-244.

10 Addison CL, Daniel TO, Burdick MD, Liu H, Ehlert JE, Xue YY, Buechi L, Walz A, Richmond A, Strieter RM: The CXC chemokine receptor 2, CXCR2, is the putative receptor for ELR+ CXC chemokine-induced angiogenic activity. J Immunol 2000;165:5269-5277. 
11 Armstrong DA, Major JA, Chudyk A, Hamilton TA: Neutrophil chemoattractant genes KC and MIP-2 are expressed in different cell populations at sites of surgical injury. J Leukoc Biol 2004; 75:641-648.

12 Scapini P, Morini M, Tecchio C, Minghelli S, Di Carlo E, Tanghetti E, Albini A, Lowell C, Berton G, Noonan DM, Cassatella MA: CXCL1/macrophage inflammatory protein2 -induced angiogenesis in vivo is mediated by neutrophil-derived vascular endothelial growth factor-A. J Immunol 2004; 172:50345040.

13 Benelli R, Morini M, Carrozzino F, Ferrari N, Minghelli S, Santi L, Cassatella M, Noonan DM, Albini A: Neutrophils as a key cellular target for angiostatin: implications for regulation of angiogenesis and inflammation. FASEB J 2002;16:267-269.

14 Dubravec DB, Spriggs DR, Mannick JA, Rodrick ML: Circulating human peripheral blood granulocytes synthesize and secrete tumor necrosis factor alpha. Proc Natl Acad Sci USA 1990;87:6758-6761.

15 Yoshida S, Ono M, Shono T, Izumi H, Ishibashi T, Suzuki H, Kuwano M: Involvement of interleukin-8, vascular endothelial growth factor, and basic fibroblast growth factor in tumor necrosis factor alpha-dependent angiogenesis. Mol Cell Biol 1997; 17:4015-4023.

16 Schruefer R, Lutze N, Schymeinsky J, Walzog B: Human neutrophils promote angiogenesis by a paracrine feedforward mechanism involving endothelial interleukin-8. Am J Physiol Heart Circ Physiol 2005;288:H1186-H1192.

17 Scharffetter-Kochanek K, Lu H, Norman K, van Nood N, Munoz F, Grabbe S, McArthur M, Lorenzo I, Kaplan S, Ley K, Smith CW, Montgomery CA, Rich S, Beaudet AL: Spontaneous skin ulceration and defective $\mathrm{T}$ cell function in CD18 null mice. J Exp Med 1998; 188:119-131.

18 Willeke T, Schymeinsky J, Prange P, Zahler S, Walzog B: A role for Syk-kinase in the control of the binding cycle of the beta2 integrins (CD11/CD18) in human polymorphonuclear neutrophils. J Leukoc Biol 2003;74:260-269.

19 Chomczynski P, Sacchi N: Single-step method of RNA isolation by acid guanidinium thiocyanate-phenol-chloroform extraction. Anal Biochem 1987;162:156-159.

20 Gasperini S, Calzetti F, Russo MP, De Gironcoli M, Cassatella MA: Regulation of GRO alpha production in human granulocytes. J Inflamm 1995;45:143-151.

21 Grotendorst GR, Smale G, Pencev D: Production of transforming growth factor beta by human peripheral blood monocytes and neutrophils. J Cell Physiol 1989;140:396-402.

22 Loukinova E, Dong G, Enamorado-Ayalya I, Thomas GR, Chen Z, Schreiber H, Van Waes C: Growth regulated oncogene-alpha expression by murine squamous cell carcinoma promotes tumor growth, metastasis, leukocyte infiltration and angiogenesis by a host CXC receptor-2 dependent mechanism. Oncogene 2000; 19:3477-3486.
23 Roberts AB, Sporn MB, Assoian RK, Smith JM, Roche NS, Wakefield LM, Heine UI, Liotta LA, Falanga V, Kehrl JH, Fauci AS: Transforming growth factor type beta: rapid induction of fibrosis and angiogenesis in vivo and stimulation of collagen formation in vitro. Proc Natl Acad Sci USA 1986;83:4167-4171.

24 Takada T, Kinkori T, Muramatsu H, Hayakawa A, Torii S, Muramatsu T: Midkine, a retinoic acid-inducible heparin-binding cytokine, is a novel regulator of intracellular calcium in human neutrophils. Biochem Biophys Res Commun 1997;241:756-761.

25 Takada T, Toriyama K, Muramatsu H, Song XJ, Torii S, Muramatsu T: Midkine, a retinoic acid-inducible heparin-binding cytokine in inflammatory responses: chemotactic activity to neutrophils and association with inflammatory synovitis. J Biochem 1997;122:453-458.

26 Sato W, Kadomatsu K, Yuzawa Y, Muramatsu $\mathrm{H}$, Hotta N, Matsuo S, Muramatsu T: Midkine is involved in neutrophil infiltration into the tubulointerstitium in ischemic renal injury. $\mathrm{J}$ Immunol 2001;167:3463-3469.

27 Choudhuri R, Zhang HT, Donnini S, Ziche M, Bicknell R: An angiogenic role for the neurokines midkine and pleiotrophin in tumorigenesis. Cancer Res 1997;57:1814-1819.

28 Muramaki M, Miyake H, Hara I, Kamidono S Introduction of midkine gene into human bladder cancer cells enhances their malignant phenotype but increases their sensitivity to antiangiogenic therapy. Clin Cancer Res 2003;9: 5152-5160.

29 Ikematsu S, Yano A, Aridome K, Kikuchi M, Kumai H, Nagano H, Okamoto K, Oda M, Sakuma S, Aikou T, Muramatsu H, Kadomatsu $\mathrm{K}$, Muramatsu T: Serum midkine levels are increased in patients with various types of carcinomas. Br J Cancer 2000;83:701-706.

30 Mecklenburgh KI, Walmsley SR, Cowburn AS, Wiesener M, Reed BJ, Upton PD, Deighton J, Greening AP, Chilvers ER: Involvement of a ferroprotein sensor in hypoxia-mediated inhibition of neutrophil apoptosis. Blood 2002; 100:3008-3016.

31 Semenza GL: Targeting HIF-1 for cancer therapy. Nat Rev Cancer 2003;3:721-732.

32 Wang SC, Lien HC, Xia W, Chen IF, Lo HW, Wang Z, Ali-Seyed M, Lee DF, Bartholomeusz G, Ou-Yang F, Giri DK, Hung MC: Binding at and transactivation of the COX-2 promoter by nuclear tyrosine kinase receptor ErbB-2. Cancer Cell 2004;6:251-261.

33 Oda N, Abe M, Sato Y: ETS-1 converts endothelial cells to the angiogenic phenotype by inducing the expression of matrix metalloproteinases and integrin beta3. J Cell Physiol 1999; 178:121-132.

34 Dewald B, Bretz U, Baggiolini M: Release of gelatinase from a novel secretory compartment of human neutrophils. J Clin Invest 1982;70: $518-525$.

35 Derynck R, Akhurst RJ, Balmain A: TGF-beta signaling in tumor suppression and cancer progression. Nat Genet 2001;29:117-129.
36 Shapiro SD: Matrix metalloproteinase degradation of extracellular matrix: biological consequences. Curr Opin Cell Biol 1998;10:602608

37 Iwasaka C, Tanaka K, Abe M, Sato Y: Ets-1 regulates angiogenesis by inducing the expression of urokinase-type plasminogen activator and matrix metalloproteinase- 1 and the migration of vascular endothelial cells. J Cell Physiol 1996;169:522-531.

38 Heiple JM, Ossowski L: Human neutrophil plasminogen activator is localized in specific granules and is translocated to the cell surface by exocytosis. J Exp Med 1986;164:826-840.

39 Brandes ME, Mai UE, Ohura K, Wahl SM: Type I transforming growth factor-beta receptors on neutrophils mediate chemotaxis to transforming growth factor-beta. J Immunol 1991;47:1600-1606.

40 Pepper MS: Transforming growth factor-beta: vasculogenesis, angiogenesis, and vessel wall integrity. Cytokine Growth Factor Rev 1997; 8:21-43.

41 Goumans MJ, Lebrin F, Valdimarsdottir G: Controlling the angiogenic switch: a balance between two distinct TGF-beta receptor signaling pathways. Trends Cardiovasc Med 2003; 13:301-307.

42 Pertovaara L, Kaipainen A, Mustonen T, Orpana A, Ferrara N, Saksela O, Alitalo K: Vascular endothelial growth factor is induced in response to transforming growth factor-beta in fibroblastic and epithelial cells. J Biol Chem 1994;269:6271-6274.

43 Sehgal I, Thompson TC: Novel regulation of type IV collagenase (matrix metalloproteinase9 and -2) activities by transforming growth factor-beta1 in human prostate cancer cell lines. Mol Biol Cell 1999;10:407-416.

44 Bohnsack JF, Zhou XN: Divalent cation substitution reveals CD18- and very late antigendependent pathways that mediate human neutrophil adherence to fibronectin. J Immunol 1992;149:1340-1347.

45 Lawson MA, Maxfield FR: $\mathrm{Ca}^{2+}$ - and calcineurin-dependent recycling of an integrin to the front of migrating neutrophils. Nature 1995; 377:75-79.

46 Muller WA, Weigl SA, Deng X, Phillips DM: PECAM-1 is required for transendothelial migration of leukocytes. J Exp Med 1993;178: 449-460.

47 Kreis C, La Fleur M, Menard C, Paquin R, Beaulieu AD: Thrombospondin and fibronectin are synthesized by neutrophils in human inflammatory joint disease and in a rabbit model of in vivo neutrophil activation. J Immunol 1989;143:1961-1968.

48 Iruela-Arispe ML, Luque A, Lee N: Thrombospondin modules and angiogenesis. Int J Biochem Cell Biol 2004;36:1070-1078.

49 Niiro H, Otsuka T, Izuhara K, Yamaoka K, Ohshima K, Tanabe T, Hara S, Nemoto Y, Tanaka Y, Nakashima H, Niho Y: Regulation by interleukin-10 and interleukin-4 of cyclooxygenase-2 expression in human neutrophils. Blood 1997;89:1621-1628. 
50 Matzner Y, Bar-Ner M, Yahalom J, Ishai-Michaeli R, Fuks Z, Vlodavsky I: Degradation of heparan sulfate in the subendothelial extracellular matrix by a readily released heparanase from human neutrophils. Possible role in invasion through basement membranes. J Clin Invest 1985;76:1306-1313.

51 John A, Tuszynski G: The role of matrix metalloproteinases in tumor angiogenesis and tumor metastasis. Pathol Oncol Res 2001;7:14-23.

52 Iniguez MA, Rodriguez A, Volpert OV, Fresno M, Redondo JM: Cyclooxygenase-2: a therapeutic target in angiogenesis. Trends Mol Med 2003;9:73-78.

53 Tasiemski A, Hammad H, Vandenbulcke F, Breton C, Bilfinger TJ, Pestel J, Salzet M: Presence of chromogranin-derived antimicrobial peptides in plasma during coronary artery bypass surgery and evidence of an immune origin of these peptides. Blood 2002;100:553-559.
54 Kullander K, Klein R: Mechanisms and functions of Eph and ephrin signalling. Nat Rev Mol Cell Biol 2002;3:475-486.

55 Ramchandran R, Dhanabal M, Volk R, Waterman MJ, Segal M, Lu H, Knebelmann B, Sukhatme VP: Antiangiogenic activity of restin, $\mathrm{NC10}$ domain of human collagen $\mathrm{XV}$ : comparison to endostatin. Biochem Biophys Res Commun 1999;255:735-739.

56 Triebel S, Blaser J, Gote T, Pelz G, Schuren E, Schmitt M, Tschesche H: Evidence for the tissue inhibitor of metalloproteinases-1 (TIMP1) in human polymorphonuclear leukocytes. Eur J Biochem 1995;231:714-719.

57 Sang QX: Complex role of matrix metalloproteinases in angiogenesis. Cell Res 1998;8:171177.
58 Liu XH, Kirschenbaum A, Yu K, Yao S, Levine AC: Cycloxygenase-2 suppresses hypoxia-induced apoptosis via a combination of direct and indirect inhibition of $\mathrm{p} 53$ activity in a human prostate cancer cell line. J Biol Chem 2005;280:3817-3823.

59 Harada H, Nakagawa K, Saito M, Kohno S, Nagato S, Furukawa K, Kumon Y, Hamada K, Ohnishi T: Introduction of wild-type p53 enhances thrombospondin-1 expression in human glioma cells. Cancer Lett 2003;191:109119.

60 Walzog B, Scharffetter-Kochanek K, Gaehtgens P: Impairment of neutrophil emigration in CD18-null mice. Am J Physiol 1999;276: G1125-G1130.

61 Carmeliet P, Jain RK: Angiogenesis in cancer and other diseases. Nature 2000;407:249257. 